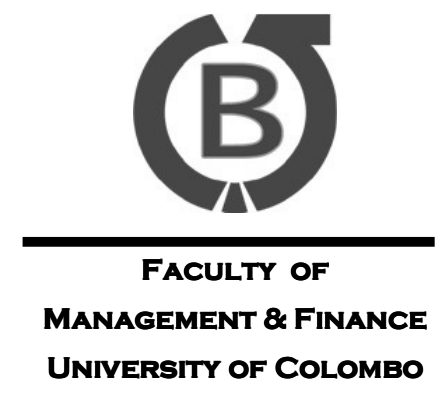

UNIVERSITY OF COLOMBO
Vol. 07, No. 02, December, 2016
Colombo

Business

Journal

International Journal

of Theory \& Practice

\title{
Customer Relationship Management (CRM) Practices in the Hotel Sector from the Perspective of Leisure Travelers
}

\author{
Maduka Udunuwara ${ }^{a 1}$, Dale Sanders ${ }^{\mathrm{b}}$, Hugh Wilkins ${ }^{\mathrm{c}}$ \\ ${ }^{a}$ Department of Marketing, University of Colombo, Sri Lanka \\ ${ }^{b c}$ School of Business, Edith Cowan University, Australia
}

\begin{abstract}
Customer relationship management (CRM) is widely discussed in numerous industries including the hotel sector. Much of the discussions on CRM have focused on implementations related aspects with only scant attention given to the CRM practices that manifest due to CRM implementations. As a result while the existing understanding on CRM has been established through an organisations point of view by identifying the back stage CRM from the point of view of the organisation, this study demonstrates the importance to enhance the understating of CRM through the customers' point of view. Thus this study explored CRM practices experienced by the leisure travellers in the hotel context and what they think of such practices. Data was collected through focus groups which consisted of 22 participants in total. The findings indicated numerous customer relationship management practices experienced by leisure travellers at the: pre-encounter, encounter and post-encounter stages.
\end{abstract}

Keywords: Customer Relationship Management (CRM), Hotels, Leisure Travel

\section{Introduction}

Customer Relationship Management (CRM) is gaining increasing attention from both researchers and practitioners, particularly in the services domain (Shamma, 2015; Payne \& Frow, 2013; Parvatiyar \& Sheth, 2001). CRM emerged in the 1990s' (Öztaysi, Sezgin, \& Özok, 2011), and its importance in the twenty first century continues to grow (Kim, Suh, \& Hwang, 2003; Nairn, 2002). Going beyond attracting customers, CRM emphasises the role of retaining customers (Zikmund, McLeod, \& Gilbert, 2003). Thus, CRM extends a transaction, to the maintenance of long-term relationships. As pointed out by Armstrong, Adam, Denize, and Kotler (2010), CRM is the most important concept in modern marketing, and a key ingredient in building customer value and satisfaction. 
The importance placed on CRM by practitioners is evident from the estimations of global expenditure on CRM implementations and related services amounting to over USD 100 billion (Payne \& Frow, 2013). The scholarly interest in CRM is evident from the increasing number of publications. The focus of much of the research on CRM, however, has been on the backstage implementation of the concept by companies and organisations. Less is known about the front stage practices of CRM and customers' experiences of CRM. Moreover, it is also observed that much of the CRM discussions initiated by software vendors from an implementations point of view have curtailed the inclusion of the customers' point of view. This study focuses on identifying the CRM practices experienced by the customer and their perceptions on such practices to generate repeat visitation and word-of-mouth in the hotel domain. This paper commences with a review of the literature on CRM and CRM in the hotel sector. It then presents the findings of the current study, followed by a discussion in relation to the literature and finally a conclusion and recommendations for future research.

\section{Literature Review}

This section provides an over view of CRM in general and CRM in the hotel context in particular.

\subsection{Overview of Customer Relationship Management (CRM)}

Definitions of CRM are largely framed by its forms; strategic, analytical and operational (Buttle, 2004; Iriana \& Buttle, 2007, Reinartz Krafft, \& Hoyer, 2004). Strategic CRM is defined by Buttle (2004, p.3) as "a top-down perspective on CRM which reviews CRM as a core customer-centric business strategy that aims at winning and keeping profitable customers". It reflects the philosophy of the organisation and a customer centric approach and is aimed at deepening the knowledge about customers through four main components: customer management orientation, implementation and alignment of organisational process, information capture and alignment of technology and CRM strategy implementation (Buttle, 2004; Iriana \& Buttle, 2007; Kumar \& Reinartz, 2006). Analytical CRM is defined as "a bottom-up perspective on CRM which focuses on the intelligent mining of customer data for strategic or tactical purposes" (Buttle, 2004, p. 3). Operational CRM is defined as "a perspective on CRM which focuses on major automation, sales force or marketing automation" (Buttle, 2004, p. 3). Operational CRM is concerned with the automation of tasks related to the customer-facing level which focus on the total customer experience (Kumar \& Reinartz, 2006). This study adapts the definition of Dyché (2002 p. 4) who defines CRM as: "the infrastructure that enable the delineation of an increase in customer value, and the correct means by which to motivate valuable customers to remain loyal-indeed, to buy again".

CRM objectives are guided by two key concepts; value and customer orientation. Firstly, 'value' plays a significant role in customer retention (Harwood \& Garry, 2006; Veloutsou, Saren, \& Tzokas, 2002). It can be explained from both the perspective of the customer and the organisation. Customers perceive value when the benefits of staying with one service firm significantly exceeds the associated costs of switching to another, whereas the firms perceive value based on the economic deliverables (Lovelock, Patterson, \& Wirtz, 2011, p. 366). Secondly, 'customer centricity' (Parvatiyar \& Sheth, 2001) which is also known as customer orientation (Akroush, Dahiyat, Gharaibeh, \& Abu-Lail, 2011; Morgan \& Hunt, 1994) also plays an important role in CRM objectives. This concept is also a key determinant of value creation. It facilitates the delivery of goods and services according to customer requirements. Focusing on the above concepts, CRM assists marketers to provide an offer beyond customer expectations, and to focus on a win-win situation for both parties in the exchange (Gummesson, 2008). 
The potential to generate benefits to both organisations and customers provides strong grounds for adopting CRM (Osman, Hemmington, \& Bowie, 2009). CRM systems are used to get to know the consumers, their likes and dislikes (Randal \& Kurt, 2013). It then facilitates customisation according to the customers' needs which leads to, customer satisfaction, customer retention, loyalty, customer lifetime value, increased business performance, sales growth, and even employee satisfaction (Amoako, Arthur, Bandoh, \& Katah, 2012; Davids, 1999; Law, Ennew, \& Mitussis, 2013; Vogt, 2010; Zikmund et al., 2003). In addition, through the maintenance of long-term relationships with the organisation, customers receive confidence benefits such as knowing what to expect from the service encounter and less service anxiety, and the social benefits such as being recognised by employees, special treatment, price discounts, faster customer service and added services (Gwinner, Gremler, \& Bitner, 1998).

\subsection{Customer Relationship Management (CRM) in the Hotel Sector}

CRM is significant to hotels (Luck \& Lancaster, 2013; Singala, 2005). They have adopted CRM practices in response to changes in the globalised business environment including technology and social media that provide customers with more booking options and the ability to assess hotels based on personal feedback/ ratings (Nasution \& Moavondo, 2008; Shirazi \& Som, 2011; Gilbert, PowellPerry, \& Widijoso, 1999; Banga, Kumar, \& Goyal, 2013). Developments in IT infrastructure have assisted hotels to in implement CRM effectively (Özgener \& İraz, 2006). CRM provides the hotel sector with an important mechanism to differentiate what is often a homogeneous core product, a nightly room (Kandampully \& Suhartanto, 2000; Luck \& Lancaster, 2003; Bowen \& Shoemaker, 1998; Zineldin, 1999).

The hotel sector is an information sensitive industry (Piccoli, Connor, Capaccioli, \& Alvarez, 2003). Customer information plays a crucial role in practicing CRM in response to the challenge of convenient access to a plethora of information available through user generated content (Rosman \& Stuhura, 2013). Information is now freely available with no restrictions, creating a wider choice for travellers and as a result, switching becomes a more convenient and an appealing option (Gilbert et al., 1999). Consequently, hotels are experiencing high customer turnover, and growing customer acquisition costs (Nasution \& Moavondo, 2008; Shirazi \& Som, 2011).

Similar to mainstream CRM research, studies in the hotel context have focused on implementation-related aspects (Lo, Stalcup, \& Lee, 2010; Luck \& Lancaster, 2003). Research includes investigations into enhancing CRM implementations (Padilla-Meléndez \& Garrido-Moreno, 2013; Sarmaniotis, Assimakopoulos, \& Papaioannou, 2013; Singala, 2005), and the identification of the importance of top management support, employee training and motivation along with organisational structure and processes (Padilla-Meléndez \& Garrido-Moreno 2013). Effective customer communication strategy, profitable marketing strategies, IT infrastructure, suitable organizational strategy, and administrative support have also been identified as key factors affecting CRM implementations (Singala, 2005).

Numerous practices related to customer-facing CRM in the hotel context have been identified by researchers. For example, Fletcher (2001) contends that in the past, CRM was practiced in simple ways, such as remembering the customers, knowledge of the customers' needs and habits, conversational patterns and interpersonal skills. Despite the extensive use of technology, modern-day customer-facing CRM has similar practices. These include, constantly keeping in touch with customers, personalised messages, extra frequent flyer miles or discounts on other products, special 
deals, due recognition (Zikmund et al., 2003), addressing the customer by name (Adams, 2001; Vogt, 2010), loyalty programs, websites and personalised emails, and other efforts to build and maintain profitable customer relationships by identifying and satisfying customer needs and expectations (Akroush et al., 2011).

Despite the plethora of CRM practices in the hotel domain, with the exception of loyalty programs, they have been subject to limited empirical research. Studies that have been undertaken include; Bowen \& Shoemaker's (1998) research into luxury hotel leisure and business guests in New York. They identified that the most important CRM practices influencing loyalty in the hotel sector were receiving upgrades, the ability to check in and out at any time, using past information to customise service, ability to request a preferred room number, employees' attitudes that demonstrates the problems of customers are important to them, and expediting the registration process for return customers. Kim, Han, and Lee (2001) determined the effectiveness of customer-facing practices on relationship quality, and the impact of relationship quality on commitment, repeat visitation and wordof-mouth using a sample consisting of luxury hotel guests in Korea. They found that effective use of relationship marketing can positively influence repeat visitation and word-of-mouth. $\mathrm{Wu}$ and $\mathrm{Li}$ (2011) investigated the strength of relationships among CRM, relationship quality and customer life time value based on a sample of hotel guests in Taiwan. Their results indicate that CRM has a positive influence on relationship quality, while relationship quality has a positive influence on customer lifetime value.

Kim et al. (2001) and $\mathrm{Wu}$ and $\mathrm{Li}$ (2011) determined the causal relationship between CRM and its outcomes through relationship quality, whereas Bowen and Shoemaker (1998) determined the relationship through trust and commitment. Moreover, all the researchers determined the effectiveness of CRM through a mix of behavioural and attitudinal dimensions. All three studies investigated travellers who visit a particular place and the sample compositions were a mix of people travelling both for leisure and business. In contrast to the above studies, this paper presents the results of a study into the impact of CRM across a range of destinations exclusively in the leisure travel market.

\section{Methods}

This research used qualitative research methods to explore the role of CRM amongst hotel leisure guests. Data collection was approved by the university's ${ }^{1}$ ethics committee and carried out through five focus groups with a total of 22 participants. Participants were recruited through purposive sampling. It was considered the most suitable method since it was not the intention to make generalisations to a larger population (Kitzinger \& Barbour, 1999; Stewart et al., 2007). All participants were Australian travellers who had visited the same destination three or more times for leisure purposes. The analysis of qualitative data began with coding (Miles, Huberman, \& Saldaña, 2014). The inductive method of coding (or in other words open coding) (Corbin \& Strauss, 2008), was facilitated through the use of NVivo software. This expedited the categorisation of data under important themes and assisted in the identification of important paragraphs, sentences and words (Corbin and Strauss, 2008). Even though the researcher had an a priori notion of the themes by means of the literature review, the coding was not restricted to a predetermined list of codes. The data revealed that CRM experiences could be classified based on the three purchase zones, pre encounter, encounter stage and post encounter. The focus groups facilitated in-depth exploration on the concepts

\footnotetext{
${ }^{1}$ Refers to the university of $2^{\text {nd }}$ and $3^{\text {rd }}$ authors. Ethics clearance was obtained from this university since data was collected in Australia
} 
under discussion which resulted in richer data. Reporting of focus group data is based on the individual respondents' views.

\section{Findings}

The results will be presented based on the three purchase zones, pre encounter, encounter stage and post encounter followed by findings related to CRM and repeat visitation and word-of-mouth marketing.

\subsection{Pre Encounter}

With the exception of interactions with hotel websites, CRM practices at the pre-encounter stage were the least experienced by the participants. Web sites were identified as an important tool with which to form relationships with the customer. However, many participants indicated their preference for using booking sites as opposed to hotel websites due to concerns about higher prices compared to booking sites. A few of them also indicated the advantages of gaining information from the people who share information through booking sites compared to hotel websites. Elaborating his experience Sam stated:

We book our hotels through booking sites rather than hotel sites... so we book through hotel club and we would get dollars off next time we book through hotel club. [FG: 4]

Gloria from the same focus group added:

You never go through the hotel websites because that's too expensive.

Bella from the same focus group presented a different experience, highlighting the availability of immediate communication stating:

Yes absolutely. That's easy. There is an online chat. If you need to speak to someone you can straight away do that. They are right there to take your call and they will help you out, and they are very friendly. [FG: 4]

Another useful element of hotel websites was identified by Sonya who discussed 'virtual trips' and her interest in such practices due to the tangible and detailed information received through them, ...sometimes when you book they ask you to view the room before you actually take the rooms. We did that on our last trip to New Zealand. You are just put into a town to have a look around at what is available; and you would go and have a look at how the rooms look like before you actually book. [FG: 4]

Pre-encounter CRM practices play an important role in generating a relationship with customers. At this stage CRM provides information to facilitate relationship building with the participants when they plan their holidays. In this study, customer experience of pre-encounter CRM in the hotel context was limited to websites.

\subsection{Encounter Stage}

Customer service, personal touch, people, additional services and cross selling were among the encounter stage practices experienced by participants. Customer service was the most experienced and discussed CRM practice with comments such as

It's really important; otherwise it ruins your holiday. [Stella, FG: 1],

Customer service should be very high. [Beth, FG: 3]

Oh customer service should be very high...of the top I think definitely. [Ben, FG: 1]

Ramona explained her experience of customer service and generalised it to hotels in India:

Well customer service was very good. It's just something that Indians do very well and I suppose our expectation is don't waited to be handed everything on a plate, common courtesy is good. [FG: 3] 
Customer service was elaborated more specifically by some participants. For example, Joyce explained her reasons for visiting the same hotel three times, based on exceptional customer service:

Someone would be at your door the minute you rang the bell you know, I like it, and they recognise you around the grounds 'how you are going' that sort of thing. [FG: 5]

Sue stated her view of customer service:

I think with customer service they are really keen to take and pass on the information, they are approachable, and willing to share their knowledge. [FG: 1]

Nadene emphasised the same point by explaining her experience of the hotel's interest in giving a good service by providing Local advice, and sharing information such as taxi charges, good roads to take to places. [FG: 3]

Good customer service was also identified as a contributor to hotel differentiation and provided a reason for repeat patronage. For example, Stella indicated customer service as a good differentiating factor among hotels stating:

How you differentiate among hotels is customer service not facilities, because they all have the same facilities more or less. [FG: 1]

Customer service is an important determinant of intention to revisit as mentioned by Stella:

Customer service is more or less an important thing that brings you back... So I think it is the service you get there as well as the facilities. Sometimes the facilities are horrible but the people are nice. If they got facilities but customer service is really bad you can't get around that a bit because it just ruins your holiday. [FG: 1$]$

The overall importance of customer service was summed up by Sam and Gloria who stated:

I think as long as the service is good and the people are warm and friendly we don't really expect a red carpet. [Sam, FG: 4]

Everything about it is friendly. How can I explain it? I get off the plane and walk in the door and I feel completely and utterly relaxed and safe and welcome and it's like I am home. [Gloria, FG: 4]

Personal touch and people were additional CRM encounter practices experienced by participants. Gloria stated:

They remembered me every time I went. They are just lovely people they do things especially for you. [FG: 4]

Jelena recalled her experience of how she was given individual consideration:

Personal touch ... I lost my conference bag once and someone had found it in a shopping centre, and they [the hotel] rang me since they had my business card; they rang me in Australia and said they would like to post it back. [FG: 5]

People were identified as the key factor in determining the success of customer service and the personal touch. For example, Mary stated her interest in going to the same hotel on her visits to Bali and expressed her delight with the people:

I would go to that hotel again, it was beautiful. The people were the nicest thing of them all. [FG: 5].

Additional services were also identified as important CRM practices. These included elements such as the ability to request room numbers. Gloria [FG 4] stated that it is nice when one can request a room number and airport pickups. Bella stated

Airport pickups are nice. We did that in New Zealand. We selected a hotel that had a pick up because it was the middle of the night. [FG: 4]

Cross selling was also identified as an influential CRM practice. This was highlighted by Ben, who had visited the same hotel many times. Ben recalled his experience with an offer made by the hotel, where the hotel had offered a stay at one of their newly built hotels. Ben explained: 
They built a new hotel in Jomtien which is down the coast, and they made an offer. They take you down to the new hotel and you could stay at a reduced rate... You know, they organise it. I just have to put the bags in and they drove me down there. I spent a week down there. It was really nice and I came back. [FG: 1]

Despite the importance attributed to encounter stage CRM, some participants had negative experiences. Sam explained his concerns about not getting due recognition by a hotel he visited twice: It would be nice in their computer system to somehow, if your name comes in to flag up. I think that if you have been with them several times they might upgrade you or I mean you are not necessarily getting extra money off but Um... dear Mr. Sam, you have been with us two times this year what about we send you such and such, maybe they do not give us something extra special but they recognise you. [FG: 5]

Similarly, even though the staff is attributed with a significant role in CRM, not all respondents had a positive experience with people in some hotels. Ramona shared a negative service encounter:

Wow they were rude, they were that rude or was that me? oh no they were rude... You know if we asked a question like a direction, where is the restaurant for breakfast for example, would it hurt you to smile! [FG: 3]

Service encounter stage CRM is experienced through customer service, personal touch, and special privileges such as the ability to request a room number and special services such as airport pickups and these were experienced by the participants. Cross selling was also among them. The participants in general placed a high importance on encounter stage CRM. Comparing all these factors, staff plays a key role in the delivery of encounter phase CRM. The influence of such practices to differentiate hotel offers from their competitors and also to generate repeat visits was pointed out by some participants. However, a few also mentioned their negative experiences with CRM and expressed their dissatisfaction with the shortcomings of encounter stage CRM.

\subsection{Post Purchase}

A few CRM practices experienced by the participants were identified as post-encounter stage practices. One of them was periodic emails containing information, such as special promotions. This was explained by Sue:

I do get periodic emails from them [the hotel] you know special offers or the redemption of points. [FG: 1].

Beth also stated

I don't mind the email, because you can always unsubscribe. I don't want people calling. [FG: 3].

Loyalty programs (loyalty/reward/priority cards) were also identified as a post-encounter stage CRM practice. Marshal stated his experience as:

You do get given them. I have so many in my wallet. [FG: 2]

Participants were more aware of loyalty programs in other encounters such as coffee shops compared to the hotel context. Lucy stated the ineffectiveness of loyalty programs in the hotel context compared to coffee shops.

I've got coffee shop and other ones but it would not certainly make me go to the hotel. I mean hotel

ones, loyalty cards would be nowhere.

Joana explained that there was more value in loyalty programs in other contexts compared to hotels:

Individual shop loyalty really does well, I think. When I use my coffee shop loyalty card they give a bit more for loyalty. Others I don't think they do so. It does not make me go back... We don't travel often 
enough to get value... I doubt a loyalty card would do that especially because we can't travel many times. If you travel 5 times you get one free or something like that. It would not work for us. [FG: 3]

In addition, Ben explained the limited practice of loyalty programs in general as:

They are quite up market chains aren't they? Small hotels do not bother with that. [FG: 1]

He further added,

If it's for business you do go back a lot. [FG: 1].

Bella highlighted her dissatisfaction with loyalty programs and pointed out an interesting aspect.

There are some hotel groups that actually charge for the loyalty card. So you don't always get a loyalty card free, you have to pay for some of them, which I find bizarre. [FG: 4].

Indicating some pointers to improve hotel loyalty Beth stated the importance of prioritising loyalty schemes and stated that:

If they issue loyalty schemes there should be upgrades or re upgrades something like that. A good reward system rather than this token stuff. It's just pointless. [FG: 3]

Another practice that can be categorised under post-encounter CRM is hotel communication including feedback-generating mechanisms such as questionnaires. The majority of participants expressed their inclination to provide feedback. Ben expressed his views on hotel feedback forms:

I've just been to Hong Kong. The hotel sent the questionnaire at the end asking how I enjoyed the stay, whether I was happy and everything. I filled it in. But by sending them [questionnaires and information letters] if they start annoying me that would be another point against them. I don't mind filling in a questionnaire but I don't need to know what they are doing and all unless I am ready to go personally. But if something starts annoying me it will be a negative. I don't need that. [FG: 1]

Ramona provided another perspective:

I don't mind filling the forms you know, I mean that is fair enough that's their job. You know if we are particularly disappointed and we can tell them, then we feel better about it and we feel really happy with the positive aspects of the services. I am sure they don't want to make us uncomfortable you know, their intention is to be hospitable. I am quite happy for them to contact me via email. I won't talk to them, though. [FG: 2]

Many participants had not experienced post encounter practices. Stella expressed her lack of experience of hotel post-purchase communications:

I don't think they really do that. [FG: 1]

Stella further added:

I've stayed in top-end hotels but no one has ever sent me an email. All the places I've been to have not sent emails asking whether I enjoyed my stay. [FG: 1].

\subsection{CRM, Repeat Visitation and Word-Of-Mouth}

CRM practices in general were found to be very effective in generating word-of-mouth. Sonya also explained how an acceptable standard of CRM could satisfy her and the benefits the hotel could obtain from such activities such as word-of-mouth:

We don't expect red carpet treatment, but you just expect people to be friendly and polite. Because it is usually what you get, and when you don't get, if it really stands out and you tell other people and then you would not recommend it. So it's in hotels and any person's best interest to have the stuff that meets those requirements. If you get a bad report you just would not recommend it and sometimes you just turn away. [FG: 4]

The influence of CRM in generating repeat visitation revealed mixed results. For example Ben, Stanley, Joanna, Gloria, Joyce, and Mary stated that their overall experience has influenced them to 
repeat visit the same hotel and that they would continue to do so in the future. However, some participants like Lucy explained the lack of overall influence of CRM to generate repeat visitation:

If they take notice of me it's really lovely, but it wouldn't be a criterion [to repeat visit]. [FG: 2]

She further added:

It [CRM] doesn't interest me [to repeat visit]" I like the fact that it is done. It would not have

influenced me to go back again because of that. But it is a courteous thing too. [FG: 2]

Similarly Jena stated the lack of influence of CRM practices in general on repeat visits:

It would make no difference to me whether they were fantastic I might tell other people. If Juliet ask me

if I have stayed in a really grand place in Kolkata or somewhere, if it's fantastic, I would mention it

based on my experience. [FG: 2]

As evident, while CRM has an influence on some customers to repeat visit, it has no impact on some travellers due to their preference for variety. Also some may consider factors other than CRM such as price, value for money, and location when selecting hotels due to their diminishing involvement in the hotel environment during their holiday.

\section{Discussion}

Numerous CRM practices were experienced by the participants, most notably during the encounter stage. Guided by the data, the CRM practices were classified based on the three purchase time zones: pre-encounter, encounter and post-encounter stages (Lovelock et al., 2011). Reinartz et al. (2004) have also categorised customer-facing CRM into three groups: initiation, maintenance, and termination. However, their study took an interest in implementation, which concerns back-stage CRM rather than front stage CRM which was the focus of this study. According to Cao and Gruca (2005), CRM concerns the relationship between both potential and current customers. The findings of this study further enhance the understanding of the role played by CRM in customer acquisition, satisfaction and retention.

Hotel websites including virtual experiences were identified as the first pre-encounter relationship building effort experienced by travellers prior to selecting a hotel. Even though researchers have not explicitly discussed virtual trips as a CRM practice, some have indicated hotel websites are a CRM practice. Wu and Li (2011) investigated hotel websites through items such as 'ease of searching for information about the company' and 'providing detailed maps and transportation guides'. Akroush et al (2011) also identified the importance of hotel websites in building relationships. In this study, it was identified that popularity of booking sites have overtaken and now play a more effective role than the hotel sites. The booking sites were positively evaluated by the participants for their CRM such as presenting important information on a wide range of options. One participant also acknowledged online chat, and the interactive nature of booking sites. The ability to get better prices and also the discounts offered when continuing to book hotels through the same site were also pointed out by the participants. It can be identified that some hotels may be losing opportunities for relationship development at the pre-encounter stage. While this may be due to hotels giving over the pre-encounter stage arrangements to the booking sites, investigation of such business relationships are beyond the scope of this study.

This study identified several key encounter-stage CRM practices including: customer service, personal touch, and people. Special privileges such as the ability to request a room number, and additional services such as airport pick-ups, activities for children, providing upgrades and discounts were also found to be effective encounter-stage CRM practices. Many of the travellers who have 
experienced these encounter practices were repeat visitors to a hotel. Such customer service at every touch point is congruent with Winer's (2001) assertion that this is an effective CRM practice during the encounter stage. Customer service has been widely researched in the hotel domain, although not widely in the context of CRM (Chen \& Popovich, 2003; Kim et al., 2003; Mendoza, Marius, Perez, \& Girman, 2007; Petrillose \& Brewer, 2012).

The participants identified that customer service is one of the key ways of generating effective relationships. All participants revealed the high importance they placed on customer service even if they did not intend to visit the same hotel again. They also expected different degrees of customer service. While some expect the highest degree of customer service, they also indicated the importance of personal space and their dissatisfaction with people talking to them all the time. Essentially, getting to know the customer better would enhance the hotel capability of customising such expectations.

A personal touch was also considered important by all the participants. It was explained as a feeling that the hotel provides services especially for them. Remembering the customers each time they visit and making them feel special were also identified as ways in which hotels practice the 'personal touch'. Even though such practices using the term 'personal touch' are not specifically mentioned in the literature, they are explained in other ways. For example, Bowen and Shoemaker (1998) identified the importance placed by hotel visitors on practices such as the 'ability to check in and out any time' and 'expediting the registration process for repeat customers'. They also identified the importance placed by customers on hotel's efforts to 'customise according to their needs based on past information'. While a customer being recognised by name is identified as a CRM practice (Bowen \& Shoemaker, 1998), it can also be identified as an effective way of delivering a personal touch.

The people (can also be referred to as staff) of the hotel were also given very high importance by the participants. Many authors have emphasised people as a key aspect of CRM (Chen \& Popovich, 2003; Kim, Choi, Qualls, \& Park, 2004; Mendoza et al., 2007) and they have been found to be the key determinant of customer service and the delivery of the personal touch. Bowen and Shoemaker (1998) have found that travellers place a high importance on employees communicating the attitude that, they as customers are important. Thus, people can be identified as the key to delivering the organisation's attitude to its customers.. Kim at al. (2001) also operationalized CRM through numerous dimensions related to people. The people component, has also been used to represent numerous other concepts such as service quality (Petrillose \& Brewer, 2012; Wilkins, Merrilees, \& Herrington, 2009), special offers (Adams, 2001; Vogt, 2010) and cross selling (Buttle, 2009; Dyché, 2002).

Some of the CRM practices identified were categorised as post-encounter stage including, loyalty programs (in this study loyalty programs are categorised as a post purchase practice, due to the benefits of loyalty programs being experienced in subsequent visits rather than in the visit on which it was offered), and hotel communications experienced by the customer such as exit questionnaires. Loyalty programs and exit questionnaires have also been used in some studies to identify customerfacing CRM (Wu \& Li, 2011; Bowen \& Shoemarker, 1998). In addition, numerous communication methods such as information on special offers and offers on redemption points were identified as efforts of organisations to maintain customer relationships even when customers have completed their stay. 
While frequent guest programs have become an indispensable practice (Shanshan, Wilco, \& Eric, 2011), it is widely used in the hotel industry (Xie \& Chen, 2013). Hotel loyalty programs have also been subject to numerous criticisms. Much of the literature has also pointed to the lack of effectiveness of such programs in generating loyalty and profitability (Dowling \& Uncles, 1997; Reinartz \& Kumar, 2002; Skogland \& Siguaw, 2004). While many participants in this study also indicated the relative ineffectiveness of loyalty programs, some admitted a lack of experience with such loyalty programs. Participants who also have business travel experience indicated that loyalty programs were more effective for business travel rather than leisure. As business travellers are more likely to visit the same hotel when they travel for business, due to organisational arrangements, loyalty programs may generate better value for business travellers rather than leisure travellers. This supports the findings of McCleary and Weaver (1992) and DeKay, Toh, and Raven (2009) that loyalty programs play an effective role in the upscale business travel market.

One participant in this study also criticised loyalty programs due to the cost involved in becoming a member of such programs, and the lack of influence of loyalty programs on repeat visitation. In the literature, hotel loyalty programs have been criticised for being more transactional based rather than loyalty generating (Bowen and Shoemaker, 1998). The same aspect was pointed out by a participant who referred to the benefits of loyalty offers as "token stuff". The lack of influence of loyalty programs on the participants may be due to longer term and less tangible benefits particularly for leisure travel. In addition, the reduced frequency of travel compared to some other purchases and the lengthy wait to receive benefits on subsequent trips tend to make them less effective for leisure travel. Despite the above findings, it is important to note that this study discussed CRM practices in general and did not involve a detailed discussion of loyalty programs. Shanshan et al. (2011) have also indicated the importance of empirical research on a wider range of CRM practices other than loyalty programs.

The hotel communications at the post-encounter stage were also discussed by the participants. Similar to their experience with loyalty programs, while some participants have experienced attempts by hotels to communicate with them after their stay, some had not. In general, participants explained that they are happy to fill in questionnaires and rationalised that the intention of the hotels in obtaining feedback is to show their concern and to provide a better service in the future. It was also mentioned as an opportunity for them to express concerns to the service providers. Nevertheless some participants said they did not like being pushed to fill in questionnaires, and preferred not to be contacted via phone to provide such feedback. In addition to feedback, a few indicated their experience of communications after purchase such as special offers and redemption points. Such attempts can be identified as effective ways of keeping in touch with visitors.

\section{Conclusion}

The classification of CRM into three categories revealed that encounter-stage CRM practices are the most effective in generating repeat visitation. Many participants were less interested in engaging in long-term relationships with the hotels and preferred to seek out new accommodation experiences. Nevertheless, participants who prefer variety also considered such practices important and stated that such efforts would induce them to generate word-of-mouth recommendation. Consequently, even though CRM may not always be an effective tool in retaining customers, it is an important practice due to its ability to generate word-of-mouth. 
Linking the expectations of CRM and the three purchase time zones, this study found that preencounter CRM is more effective in acquiring new customers, while encounter-stage CRM has an influence on retaining customers. Similarly, the post purchase CRM may be capable of enhancing customer relationships. Even though much of the discussions on CRM emphasise the maintenance of profitable customer relationships (Buttle, 2009; Cao \& Gruca, 2005) this study identified the importance of building relationships from the time the customer starts searching for options. Thus the pre- encounter stage, encounter stage and post encounter stage are vital for relationship development efforts involving both potential and current hotel customers.

Thus it is recommended that future studies are undertaken to specifically investigate the pre encounter, encounter and post encounter stage CRM practices of hotels. The effectiveness of such practices to generate repeat visitation and word-of-mouth can be identified through a quantitative study. Further studies can address more about the practices employed during three stages will provide detailed knowledge on both the hotels' implementation of the practices as well as how the customers perceive these practices to achieve the expected benefits of CRM which will contribute to more effective use of CRM.

\section{References}

Adams, B. (2001). Customer relationship management uncovers revenues from loyal guests'. Hotel \& Motel Management, 216(9), 36-37.

Akroush, M. N., Dahiyat, S. E., Gharaibeh, H. S., \& Abu-Lail, B. N. (2011). Customer relationship management implementation: An investigation of a scale's generalizability and its relationship with business performance in a developing country context. International Journal of Commerce and Management, 21(2), 158-190.

Amoako, G. K., Arthur, E., Bandoh, C., \& Katah, R. K. (2012). The impact of effective customer relationship management (CRM) on repurchase: A case study of (Golden Tulip) hotel (AccraGhana). African Journal of Marketing Management, 4(1), 17-29.

Armstrong, G., Adam, S., Denize, S., \& Kotler, P. (2010). Principles of marketing (5 ${ }^{\text {th }}$ ed.). Australia: Pearson.

Banga, G., Kumar, B., \& Goyal, H. (2013). Customer relationship management in hotel industry. Pacific Business Review International, 5, 71-81.

Bowen, J. T., \& Shoemaker, S. (1998). Loyalty: A strategic commitment. Cornell Hotel and Restaurant Administration Quarterly, 39(1), 12-25.

Buttle, F. (2004). Customer relationship management: Concepts and tools. Amsterdam: Elsevier Butterworth-Heinemann.

Buttle, F. (2009). Customer relationship management: Concepts and technologies ( $2^{\text {nd }}$ ed.). London: Butterworth-Heinemann.

Cao, Y., \& Gruca, T. S. (2005). Reducing adverse selection through customer relationship management. Journal of Marketing, 69(4), 219-229.

Chen, I. J., \& Popovich, K. (2003). Understanding customer relationship management (CRM): People, process and technology. Business Process Management Journal, 9(5), 672-688.

Corbin, J. M., \& Strauss, A. L. (2008). Basics of qualitative research: Techniques and procedures for developing grounded theory. Thousand Oaks, Calif: SAGE.

Davids, M. (1999). How to avoid the 10 biggest mistakes in CRM. Journal of Business Strategy, 20(6), 22-26.

DeKay, F., Toh, R. S., \& Raven, P. (2009). Loyalty programs: Airline outdo hotels. Cornell Hospitality Quarterly, 50(3), 371-382. 
Dowling, G. R., \& Uncles, M. (1997). Do customer loyalty programs really work? Sloan Management Review, 38(4), 71-82.

Dyché, J. (2002). The CRM handbook: A business guide to customer relationship management. Boston: Addison Wesley.

Fletcher, L. A. (2001). Going beyond the buzzword: What exactly is CRM? Learned Publishing, 14(3), 213-222.

Gilbert, D. C., Powell-Perry, J., \& Widijoso, S. (1999). Approaches by hotels to the use of the internet as a relationship marketing tool. Journal of Marketing Practice: Applied Marketing Science, 5(1), 21-38.

Gummesson, E. (2008). Total relationship marketing ( $3^{\text {rd }}$ ed.). Oxford: Butterworth-Heinemann.

Gwinner, K. P., Gremler, D. D., \& Bitner, M. J. (1998). Relational benefits in services industries: The customer's perspective. Journal of the Academy of Marketing Science, 26(2), 101-114.

Harwood, T. G., \& Garry, T. (2006). Relationship marketing: Why bother? Handbook of Business Strategy, 7(1), 107-111.

Iriana, R., \& Buttle, F. (2007). Strategic, operational, and analytical customer relationship management: Attributes and measures. Journal of Relationship Marketing, 5(4), 23-42.

Kandampully, J., \& Suhartanto, D. (2000). Customer loyalty in the hotel industry: The role of customer satisfaction and image. International Journal of Contemporary Hospitality Management, 12(6), 346-351.

Kim, J. W., Choi, J., Qualls, W., \& Park, J. (2004). The impact of CRM on firm-and relationship-level performance in distribution networks. Communications of the Association for Information Systems, 14(30), 632-652.

Kim, W. G., Han, J. S., \& Lee, E. (2001). Effects of relationship marketing on repeat purchase and word of mouth. Journal of Hospitality \& Tourism Research, 25(3), 272-288.

Kim, J., Suh, E., \& Hwang, H. (2003). A model for evaluating the effectiveness of CRM using the balanced scorecard. Journal of Interactive Marketing, 17(2), 5-19.

Kitzinger, J., \& Barbour, R. S. (1999). Developing focus group research: Politics, theory, and practice. Thousand Oaks: SAGE Publications.

Kumar, V., \& Reinartz, W. J. (2006). Customer relationship management: A database approach: John Wiley \& Sons Inc.

Law, A. K. Y., Ennew, C. T., \& Mitussis, D. (2013). Adoption of customer relationship management in the service sector and its impact on performance. Journal of Relationship Marketing, 12(4), 301-330.

Lo, A. S., Stalcup, L. D., \& Lee, A. (2010). Customer realtionship management for hotels in HongKong. International Journal of Contemporary Hospitality Management, 22(2), 139-159.

Lovelock, C. H., Patterson, P., \& Wirtz, J. (2011). Services marketing: An Asia-Pacific and Australian perspective. Frenchs Forest, N.S.W: Pearson.

Luck, D., \& Lancaster, G. (2003). E-CRM: Customer relationship marketing in the hotel industry. Managerial Auditing Journal, 18(3), 213-231.

Luck, D., \& Lancaster, G. (2013). The significance of CRM to the strategies of hotel companies. Worldwide Hospitality and Tourism Themes, 5(1), 55-66.

McCleary, K. W., \& Weaver, P. A. (1992). Do business travelers who belong to frequent guest programs differ from those who don't belong? Journal of Hospitality \& Tourism Research, 15(3), 51-64.

Mendoza, L. E., Marius, A., Pérez, M., \& Grimán, A. C. (2007). Critical success factors for a customer relationship management strategy. Information and Software Technology, 49(8), 913945. 
Miles, M. B., Huberman, A. M., \& Saldaña, J. (2014). Qualitative data analysis: A methods sourcebook. Thousand Oaks, Califorinia: SAGE Publications, Inc.

Morgan, R. M., \& Hunt, S. D. (1994). The commitment-trust theory of relationship marketing. The Journal of Marketing, 20-38.

Nairn, A. (2002). CRM: Helpful or full of hype. Journal of Dataabase Marketing \& Customer Strategy Management, 9(4), 376-382.

Nasution, H. N., \& Moavondo, F. T. (2008). Customer value in the hotel industry: What managers believe they deliver and what customer experience. International Journal of Hospitality Management, 27, 204-213.

Osman, H., Hemmington, N., \& Bowie, D. (2009). A transactional approach to customer loyalty in the hotel industry. International Journal of Contemporary Hospitality Management, 21(3), 239250.

Özgener, Ş., \& İraz, R. (2006). Customer relationship management in small-medium enterprises: The case of Turkish tourism industry. Tourism Management, 27(6), 1356-1363.

Öztaysi, B., Sezgin, S., \& Özok, A. F. (2011). A measurement tool for customer relationship management processes. Industrial Management \& Data Systems, 111(6), 943-960.

Padilla-Meléndez, A., \& Garrido-Moreno, A. (2013). Customer relationship management in hotels: Examining critical success factors. Current Issues in Tourism, 17(5), 1-10.

Parvatiyar, A., \& Sheth, J. N. (2001). Customer realtioship management: Emerging practice, process, and discipline. Journal of Economic and Social Research, 3(2), 1-34.

Payne, A., \& Frow, P. (2013). Strategic customer management: Integrating relationship marketing and CRM: Cambridge University Press.

Petrillose, M. J., \& Brewer, K. P. (2012). An exploration of customer retention factors in Las Vegas casino resort properties. UNLV Gaming Research \& Review Journal, 5(2), 1.

Piccoli, G., Connor, P., Capaccioli, C., \& Alvarez, R. (2003). Customer relationship management-A driver for change in the structure of the US lodging industry. The Cornell Hotel and Restaurant Administration Quarterly, 44(4), 61-73.

Randal, R., \& Kurt, S. (2013). The implications of social media on customer relationship management and the hospitality industry. Journal of Management Policy and Practice, 14(3), 18.

Reinartz, W., Krafft, M., \& Hoyer, W. D. (2004). The customer relationship management process: Its measurement and impact on performance. Journal of Marketing Research, 41(3), 293-305.

Reinartz, W., \& Kumar, V. (2002). The mismanagement of customer loyalty. Harvard Business Review, 80(7), 86-95.

Rosman, R., \& Stuhura, K. (2013). The implications of social media on customer relationship management and the hospitality industry. Journal of Management, 14(3), 19.

Sarmaniotis, C., Assimakopoulos, C., \& Papaioannou, E. (2013). Successful implementation of CRM in luxury hotels: Determinants and measurements. EuroMed Journal of Business, 8(2), 134-153.

Shamma, H. M. (2015). Customer relationship management in professional service organizations: A strategic approach towards a sustainable competitive advantage. Revolution in Marketing: Market Driving Changes,181-181.

Shanshan, N., Wilco, C., \& Eric, S. (2011). A study of hotel frequency-guest programs: Benefits and cost. Journal of Vacation Marketing, 17(4), 315-327.

Shirazi, S. F. M., \& Som, A. P. M. (2011). Destination management and relationship marketing: Two major factors to achieve competitive advantage. Journal of Relationship Marketing, 10, 76-87.

Singala, M. (2005). Integrating customer relationship management in hotel operations: Managerial and operational implications. Hospitality Management, 24, 391-413. 
Skogland, I., \& Siguaw, J. A. (2004). Are your satisfied customers loyal? Cornell Hotel and Restaurant Administration Quarterly, 45(3), 221-234.

Veloutsou, C., Saren, M., \& Tzokas, N. (2002). Relationship marketing: What if...? European Journal of Marketing, 36(4), 433-449.

Vogt, C. A. (2010). Customer relationship management in tourism: Management needs and research applications. Journal of Travel Research, 50(4), 356-364.

Wilkins, H., Merrilees, B., \& Herington, C. (2009). The determinents of loyalty in hotels. Journal of Hospitality Marketing \& Management, 19(1), 1-21.

Winer, R. S. (2001). A framework for customer relationship management. Califonia Management Review, 43(4), 89-105.

Wu, S. I., \& Li, P. C. (2011). The relationship between CRM, RQ and CLV based on different hotel preferences. International Journal of Hospitality Management, 30, 262-271.

Xie, K. L., \& Chen, C.-C. (2013). Progress in loyalty program research: Facts, debates, and future research. Journal of Hospitality Marketing \& Management, 22(5), 463-489.

Zikmund, W. G., McLeod, R., \& Gilbert, F. W. (2003). Customer relationship management: Integrating marketing strategy and information technology. Great Britain: Wiley.

Zineldin, M. (1999). Exploring the common ground of total relationship management (TRM) and total quality management (TQM). Management Decision, 37(9), 719-730. 